\section{THE LEGACY OF}

TRADITIONAL THAI

\section{LITERATURE AND ITS IMPACT ON CONTEMPORARY \\ CHILDREN'S \\ LITERATURE $^{1}$}

\section{Ruenruthai Sujjapun ${ }^{2}$}

\begin{abstract}
Literature is a significant part of any nation's cultural heritage, its continuing existence depending on the values which are handed down from era to era, from generation to generation. Most traditional Thai literature follows the same conventions. The influence exerted by western literature helped to foster the development of contemporary Thai literature, but at the same time relegated traditional literature to the back burner, seemingly remote from contemporary Thai life. This can clearly be seen in contemporary children's literature; for example, it is obvious that at the present time the books in The Adventures of Harry Potter series by J. K. Rowling are bestsellers that have captured the hearts of children all over the world. Witches and the magic of the western world are borrowed by authors of children's literature and even play a role in some
\end{abstract}

1 Paper presented at the $9^{\text {th }}$ International Conference on Thai Studies, Northern Illinois University, DeKalb, Illinois, USA, 3-6 April 2005

2 Associate Professor, Department of Thai, Faculty of Humanities, Ramkhamhaeng University, Thailand
Thai children's books as well. Nevertheless, there are a number of Thai writers who appreciate traditional Thai literary works and who have made an effort to revive some works of traditional Thai literature both in terms of content and style. They narrate new versions of classical literature in modern form and with more up-to-date content in a manner that appeals to young readers.

Essentially, there are four basic methods which authors use to mine the rich heritage of the classical canon in Thai contemporary children's literature: first, they create new versions which are based on an old story but with some new imaginative touches added, as for example in Mucchanu; secondly, they borrow certain characters or certain motifs from traditional literary masterpieces to create new stories, as for example in The Little Garuda; thirdly, they satirize literary convention or certain motifs from traditional literature, as for example in The Magicless Prince; and fourthly, the writers transform an old tale into picture books or comic books.

The analytical study in this article is based on the theory of intertextuality, which proposes that there are no original texts and that every text is composed of literary elements that have been narrated or used before, at some point in the past. In fact, the capacity to write literature is a result of reading many traditional literary works as well as more contemporary ones.

The aim of this study is to confirm the aesthetic values of classical Thai literature whose legacy can be mined to create new forms and new content in order to appeal to new generations of readers. Therefore, traditional Thai literature is still alive and well in contemporary Thai society. 


\section{Introduction}

Children's literature exists on many levels. It can be categorized according to the age of the children in the target group, ranging from children that cannot read by themselves to adolescents. In this article, the term 'children's literature' applies to every level.

In the old days, Thai children did not have particular tales to read or listen to individually, but simply read or listened to tales together with adults. This was certainly true of most lullabies, the content of which was not composed for children; the latter merely listened or responded to the rhythm while the adults listened to the story. The tales are the same. Although the main characters are children, the story may contain cruelty, such as in the story of The Pla Boo Thong (The Golden Fish), in which the father kills the mother and the step-mother kills the step-daughter. With developments in modern education, adults are becoming increasingly aware of the importance of children's literature in stimulating children's mental and emotional growth; moreover, it helps to cultivate the thought processes and imagination of young children. The popularity of the bestselling series The Adventures of Harry Potter all around the world, including Thailand, has prompted Thai writers to revive folktales and traditional literary works, to retell them and re-create them in different literary forms and content in order to attract the attention of the younger generation. There are four ways to create contemporary children's literature based on traditional sources. The first method involves the re-creation of the story with new imaginative touches. The second involves the creation of a new story line with certain characters from old tales. The third involves a parody of certain literary conventions and motifs. The fourth involves the transformation of traditional literature into picture-book form or comics. The details will be analyzed below.

\section{The Re-creation of the Story with New Imaginative Touches}

From time to time, many works of traditional literature are re-worked again and again. The original story may become exaggerated in the process or undergo a radical change; for example, the Ramakian has many parts that are different from the original Ramayana. Some writers have retold the Ramakian for children by exaggerating certain aspects of the old story in order to make it more colourful and more exciting, The Adventure of Macchanu by Kitakal being one example.

Macchanu is the son of Hanuman and Supanmaccha. During the construction of the road to Longa, Hanuman takes up with a mermaid who gives birth to Macchanu on the seashore after Hanuman has abandoned her. The son, who is born as a monkey with the tail of a fish, is later taken in by Mayarab, the king of the sea, who adopts him as his stepson. When Mayarab puts Rama to sleep with a magic spell and carries him off to the depths of the sea, Hanuman comes to the rescue. Hanuman meets Macchanu and after fighting each other to a standstill, he realizes that Macchanu is in fact his very own son. After that, Hanuman is able to slay Mayarab and save Rama's life. He allows Waiwik, the son of the former king, to assume the vacant throne, with Macchanu as the Prince Regent.

In the Ramakian, Supanmaccha is not mentioned anymore after Macchanu is born. However, Kitakal expanded the story, relating how Supanmaccha is so hurt after Hanuman abandons her that she goes to live in the Himavant forest. Macchanu, an orphan, grows up to be a bad boy, aggressive, lacking 
in courtesy, and unhelpful. Waiwik wants to improve his younger brother's behavior, and so sends him out alone to search for his mother in Himavant, a very dangerous forest. Before Macchanu's departure, he asks him to commit three words to memory: patience, mercy and forgiveness. Waiwik disguises himself as a hermit to give him lessons.

In the Ramakian, Macchanu is 16 years old when he was born. He has white skin like his father and a fishtail like his mother. He has no magic weapon but possesses magic powers, so Hanuman is unable to defeat him. In The Adventure of Macchanu, he is five years old, with pinkish white skin and a blue tail. His magic weapon is a green lotus which can change into a razor that burnes everything in its path. Besides, Macchanu is also able to release razor-sharp weapons from the palms of his hands, make enormous waves and create a big balloon in which to imprison his enemies. In this version, Macchanu makes a very appealing hero for young children.

The writer uses a standard literary convention in the form of a long journey or quest which the main character must undertake to prove his ability. In this book, Macchanu travels alone along a very dangerous route to find his mother in the Himavant forest. During his travels, he fights with wild monkeys, quarrels with the Sun God, destroys a banana tree which is the house of the female spirit Tani, beats the giant who is the doorkeeper of Himavant and completely uproots the trees. Naratha, the great hermit, has to subdue him and sends him to Kanti, the hermit, in order to test his cleverness. Kanti orders Macchanu to use a small bowl to fill a big jar with water. First, Macchanu uses his magic with the result that the jar is broken. He tries again, but he is unable to fill the jar. On the third day, he uses a pipe to draw water from the river into the jar. At first the pipe is too small for the task, while later it is too large. Either way, Macchanu does not succeed at his given task. The next day, Macchanu goes to meet Kanti in a garden and the hermit teaches him to study patiently. He tells Macchanu that if he knows the proper methods, he will be able to use his magic properly. In the end, Macchanu learns the lesson.

After passing the test, he thinks it might be possible to finally meet his mother, but the hermit tells him that he must first pass another test. Macchanu becomes so angry that he runs away into the forest. Along the way, Tani, a female spirit, gets her revenge by pointing him in the wrong direction. Suddenly, Macchanu is faced with 12 spirits, whom he is unable to kill. However, Kanti arrives in the nick of time to rescue him. After he realizes that Kanti is in fact Waiwik, his brother, he jumps into the pond, and is able at long last to meet his mother. She embraces him and showers him with love and care; however, she tells him that it grieves her to learn that her only beloved son is such a bad boy, so aggressive and merciless. Macchanu pleads guilty as charged and promises to change his ways.

It can be seen that in The Adventure of Macchanu, the latter represents a child from a broken home, which explains his aggression, bad temper and lack of mercy. There are plenty of examples of children like him in real life. Adults should understand children like this, and must be patient and use all sorts of tricks to teach them how to behave properly since compulsion does not work. The children need to learn by themselves by putting their parents' teaching into practice. The colorful character of Macchanu in this version may inspire 
children to read this particular work, which is based on a work of classical literature.

\section{Borrowing Certain Characters to Create a New Story}

Some characters in famous literary works are borrowed, with the aim of creating brand-new stories. One example of this approach to children's literature is The Little Garuda by Khoynuch.

The garuda is a famous character both in mythology and literature. He is the son of a king named Kasayapa and his wife Winata. The king has another wife named Bhatharu who is the mother of a naga. The quarrel between these two queens results in the garuda and the naga becoming sworn enemies.

A garuda is also a main character in Kaki, a story of the love between Kaki on the one hand and Phromthat, Garuda and Khon Tanp on the other. The 'Kaki' story is influenced by the kakati jataka. There are two literary works of this name: a royal boatman's song written by Prince Thamathibet and a story in verse written by Chao Phaya Phra Klang (Hon).

Tri Bhum Phra Ruang describes how the garudas and nagas live in Himavant forest, with the garudas living in the ngiew trees near Simplee pond, and the nagas living in the deep water under Mount Sumeru.

The Little Garuda makes a garuda, a creature of Himavant, the main character. A little garuda is raised in an orphanage in a garuda village. This little garuda, however, is different from his peers in that he has a pair of little wings, like fins, on his back, and nostrils which can open and close. Besides, his feathers are black, not red. Given these differences, the little garuda is discriminated against and is often bullied by the other little garudas. As a result, he plays alone in the forest behind the village. There he makes new friends, such as a hen who crows all the time, a white crow who sings sweetly like a kiriboon, and a duck who hates water. When the garudas are four years old, all of them are taught to fly, but the little garuda is not permitted to join in the lessons. Nevertheless, he tries to fly by himself but without success. Then three bad garudas try to deceive him by telling him to find an old garuda who can teach him to fly, hoping that he will die along the way in the deep forest.

Eventually, the little garuda does indeed find the old garuda. After following him everywhere for a long time, the little garuda falls ill, but the old garuda cures him. When he examines the little garuda more closely, he suddenly throws him into the water. At first, the little garuda is frightened to death, but after a few minutes he discovers he is able to breathe under water and dives. The little garuda is astonished at his special ability and he soon grows to enjoy it. He sets out on his travels, diving in every sea around the world, eventually learning more and more until finally he becomes an expert diver.

The little garuda goes to the Sithandon Sea to prove for himself that the legend of the garuda and the naga is true. At the same time, the three bad garudas go there to prove their fighting abilities. However, when the three are pulled to the bottom of the sea, the little garuda dives in to save them. He does not fight with the naga, however, but makes friends with him. When the three garudas finally awake, they see the little garuda asleep by their side with the scale of a naga in his hand. Stealing the scale, they return to their village and claim that they were the ones that killed the naga, at the same time slandering the little garuda as an outcast who 
should be banished. The little garuda does not show up in the village anymore. Happy to have found himself, he no longer wants to be part of any group.

The Little Garuda may remind readers of other books, such as Jonathan Livingston Seagull. These two stories contain the same theme, which involves searching for and finding oneself, the courage to live differently from others and the discovery of one's own independence and freedom. The garuda in this example of children's literature is not only a creature of Himavant as he appears in other books; rather, he challenges us as readers to think what kind of 'garuda' we are. Moreover, the writer wants the reader to ponder the question of peace and harmony, so he imagines that the garuda and the naga make friends.

Besides The Little Garuda, there are some children's stories, such as The Adventure in Himavant and The Fantastical Himavant, written by Sirikan, who weaves many kinds of creatures from Himavant into her novels, including kinaree, kinara, kilin, khochasi (a cross between an elephant and a lion), kochapaksi (a cross between an elephant and a bird), durongpaksin (a cross between a horse and a bird), karinpaksa (a cross between an elephant and a bird), hemara-usdon (a cross between a horse and a swan), orhan (a bird with a female face) and thakathor (a cross between a tiger and an elephant). Both stories fall into the category of science fiction or science fantasy. The old world and the modern world are linked by a tunnel created by a very clever scientist. A kinara and a kilin cross into the world of humans to find the kinara's mother who has been kidnapped. They are helped by a boy and a girl. After that, the boy and the girl, together with their sister and their teacher, are sucked into the tunnel, landing in the Himavant forest where the four embark upon a series of amazing adventures.

\section{Parody of Certain Literary Conventions and Motifs}

Some children's literature satirizes existing literary conventions and motifs. Such works are a clear indication that the writers possess a thorough understanding of Thai literary conventions. One example of this type of approach is The Magicless Prince written by Preeda Akrachandrachot.

The plot is in the form of a fable in which a king rules over a large country. The king first sends his son to study with a hermit in the forest, but after finishing his education, the prince receives a magic weapon and sets out upon a quest to find himself a princess. He fights with some giants. Then he goes back home to become king. As a novel, The Magicless Prince is a parody, satirizing the five parts of Thai fables which are as follows:

\section{A Magic Weapon}

Every prince in Thai literature and chak chak wong wong fables receives a magic weapon at birth or from a hermit who is his mentor.

The Magicless Prince tells the story of a magic land, so-called because every prince, every princess and all the people in this land possess at least one magic weapon. The king of this land has many sons and daughters, but the main character is the $11^{\text {th }}$ prince. His brothers and sisters have one magic weapon each, such as a magic bow, a magic sword, a pair of magic shoes, magic armor, magic medicine, etc. The $11^{\text {th }}$ prince, however, has no magic weapon which is very strange and somewhat unusual. The king is very upset. He puts the queen to death because he sees this as bad luck, like a motif in many tales. In 
most of the tales, the queen is saved from persecution but in this novel, unluckily there is no one to come to her rescue.

As a result of the contempt in which he is held, the Prince loves to read books in the library. Consequently, he is very clever and learns about the world at large from books. He reads about the Himavant forest, the giants, a wishing tree (Kalapaphruk), the four great lions, etc. In this section, the writer satirizes bestselling How to books with the introduction, for example, Speaking the Kinaree language Without Tears, How to be a Good King, etc.

\section{The Hermit as Mentor}

One day the king banishes the magicless Prince to Himavant for seven years in order to study with a hermit, to search for a magic weapon, to gain fame by committing some act of bravery and to find himself a princess. Once he accomplishes these four tasks, he can return to the palace. The Prince chooses a school from a book named How to Choose a Hermit Institute. The Prince decides to study with the hermit with fiery eyes because the course syllabus states that the students will learn how to carry out the tasks of a prince, just as in a fairy tale. The annual fee is really high, but it is the oldest and the most prestigious institute in the Himavant forest. In the fables, the hermits are very intellectual, religious and have various merits. They teach their students for free, in addition to which, they give them a magic weapon upon graduation. By contrast, in this children's book, fees are exorbitantly high. The students must study for six years to graduate and anyone wanting a magic weapon must pay extra.

\section{Killing a Giant}

Fighting with one or two giants is a motif that occurs in every fable. It is an important part of many a prince's quest and provides a means by which he can prove his skill and his bravery. Again, the writer makes fun of this motif. The magicless Prince must risk his life to acquire a magic weapon because he has no money. The hermit sends the Prince to collect some saphaya, which are magic leaves, but anyone who eats them will turn into a bird. A giant named Indrakumara, who looks after the saphaya tree, happens to be a vegetarian and a peaceful kind of fellow, whom the hermit turned into stone 20 years previously. The giant allows the Prince to pick some saphaya leaves, instructing him that a green leaf will turn him into a bird, while a yellow one will turn him back into a human. The Prince is very grateful, fully intent to return later to help the hapless giant.

The 'saphaya' tree in this novel is influenced by Singhakraiphop, a verse tale written by Sunthon Phu. The story is about a giant who brought up a boy as his very own son. One day when he goes to find some food, Singhakraiphop steals into a cave where he finds a saphaya tree whose leaves come in four different colors: red, for becoming a naga; white, for becoming a monkey; green, for becoming a bird; and yellow, for turning the skin into gold. This modern work of children's literature changes the saphaya leaf into two colors only. After the Prince gives the leaves to the hermit, he receives a magic blanket as a reward. If the Prince covers himself with the golden side of the blanket, his skin will turn gold like that of a deva (god). If he covers himself with the grey side, he will turn into an ordinary fellow. 


\section{Himavant Forest}

The Himavant forest is a setting that has been used in many fables and tales. In the Himavant forest, there are many wonderful things designed to leave the audience with a sense of amazement. 'The Magicless Prince' uses the Himavant forest as a place of adventure. Himavant is home to many kinds of animals and fantastic creatures, such as a withayathon, a female fruit (nareephol), a bird with the trunk of an elephant, a flying horse, a tiger-fish, etc. The writer describes the Himavant forest as being very crowded because there are many schools for princes. The four great mountains have been destroyed to build cities. The number of animals is dwindling because the student princes hunt for pleasure. Even the four great lions are starving to death, and are sometimes obliged to eat birds, rats or ants' eggs. In this children's novel, the Himavant forest is no longer beautiful, nor is it very mysterious.

In the Himavant forest, the Prince meets the four great lions who are very skinny, dirty and graceless. Tinsi has red fur, Kalsi has black fur, Bundusi has yellow fur, while Kaison has white and red fur. These four lions are the representatives of the Himavant forest because of their frightfulness. The Prince also meets three humans. The first two are brothers; one is covered with a cow's hide, while the other is covered with a tiger's skin. This is a satire on the tales of Honvichai-Khavi. The third one is a beggar boy who asks to accompany the Prince. This reminds readers of Chinese novels (kamlungpainai novels).

\section{Marriage to a Princess}

Some of the princes and princesses in Thai folktales are born in unusual circumstances, for instance in a shell, in a tree, in a drum, etc. In this novel, the princess is born in a bamboo tree like Yorpraklin in a folk drama called Maneepichai. The princess is stolen by a withayathon because the Prince has no magic weapon. $\mathrm{He}$ has to follow the kidnapper in order to rescue the princess and save her life, which is a standard task for a prince in folktales.

During the long journey to find the princess, the Prince comes to a village called 'a simple land'. The people who live here consist of the homeless and those who have been banished from the palace because they were condemned as rebels, adulterers or just unlucky because they gave birth or were born under an evil star, i.e. their births were unusual and therefore inauspicious. From an ex-counsellor to the king, the Prince learns the true nature of things, namely that all people are forced into holding wrong beliefs; for example, giants must be bad and cruel, princes must possess a magic weapon, kill a giant and marry a princess. This excounsellor teaches him that what people really need is wisdom; that people should use their brains and make their own decisions; that they should not believe things without first questioning them or considering them seriously.

The Prince helps the citizens to fight against the princes who want to take away their land to build their cities. But, since he cannot use magic to fight them, he is eventually captured. Then the Prince realizes that magic weapons are dangerous and evil if they are used to harm others. The Prince does not want a magic weapon for himself anymore; he only wants to have one to help the weak. Later, the giant comes to help the Prince and the 
citizens by giving them saphaya leaves. Everybody turns into a bird and escapes from the magic rope. Each of the princes uses his magic weapon together. Indrakumara, the giant, and the Prince are unable to fight. At last the four lions arrive, and the princes are finally defeated and disperse. The lions make a solemn vow to make it their responsibility to restore Himavant to its rightful inhabitants, to turn it into a home for every kind of creature in the forest, and to guard the Himavant against outsiders who want to use it for their own benefit.

The Prince's final task is to save the princess from the withayathon. But the princess chooses to marry the withayathon because he has a magic weapon and he is planning to build a city. Subsequently, the Prince returns to the simple land to live out his life in peace. Later on, he discovers that the little beggar is a girl, not a boy. He marries her and lives happily ever after in his adopted land.

It can be concluded that this children's novel, entitled $A$ Magicless Prince satirizes Thai literary conventions, in addition to inserting several motifs found in traditional Thai literature and folktales. Readers of this kind of literature can understand the content and find it entertaining at the same time. Besides, the writer prompts the younger generation of readers to think about personal values, and that it is wrong to take advantage of others. The important task of human beings is to help the weak and to make oneself useful for the sake of society at large and mankind in general. The most important thing is to destroy erroneous beliefs that have been inherited over time and swallowed without thinking. Therefore, the magicless Prince goes back to his hometown to change the king's attitude. Although he fails, the Prince is glad that he has already done his duty to the best of his ability.

\section{Picture Books and Comic Books Based on Thai Literature}

Picture books and comic books are another kind of children's literature. The extensive use of cartoon pictures with text kept to a minimum is particularly suitable for kids who can not read fluently. In fact, both children and grown-ups love the picture books and comic books. Many works of Thai literature and folktales have been transformed into picture books, for instance, the Ramakian, Mahabharata, Kraithong, Phra Abhaimani and Sam Kok (the Romance of the Three Kingdom), etc. Many of these comic books appear as series, while others are published in the form of monthly magazines.

The stories in the picture books do not follow the original texts. Some parts may be severely abridged, while others are enlarged. The writers may create more incidents or characters than exist in the original for the pleasure of the readers. For instance, in the Ramavatala, after Ravana (Thosakan) completes his education with Khobut, the hermit, he dons an academic gown in order to receive his degree from the hermit. Also Ravana asks the cartoonist to take his picture. Moreover, when Ravana tests his power by flying to heaven, he meets Superman and Ultraman (the famous Japanese character in the picture book and film) who happen to be flying in the same direction. The appearance of Superman and Ultraman is so funny because the children know these two characters. The Ramavatala also extends the story of making the ambrosia at Kasian Samut which causes the feud between the naga and the garuda. 
The picture book version of Kraithong is different from the dramatic version. The original story relates how Chalawan steals Tapaothong, the daughter of a wealthy man. Kraithong volunteers to bring her back. He has many magic weapons at his disposal: a lance made from a very hard metal, a candle which can open up a passage in water, a magic coat and a string of magic beads. In the end, Kraithong is victorious and marries both Tapaokaew and Tapaothong. Later, he dives back to get Wimala and Luemlaiwan, Chalawan's wives, to make them his third and fourth wives. After a jealous quarrel, Wimala turns into a female crocodile, runs amok and flees into the water. The picture book version of Kraithong is published as an ongoing series, with no. 9 being the most recent to appear. The picture book version tells how Chalawan abducts Tapaokaew and how Kraithong helps her by using his magic kris (Malay dagger). He is able to hurt Chalawan but is unable to defeat him. His teacher comes to save both him and Tapaokaew. Badly injured, Chalawan dives back to his cave where he is confronted by Princess Wimala, a daughter of the King of the Crocodiles, who scolds him for causing so much trouble. Chalawan becomes so angry that he rapes her, but gets more badly hurt when Wimala calls out to Kraithong for help. The next series promises to be more exciting, even though the original text has been somewhat distorted.

\section{Conclusion}

It can be seen that many aspects of traditional Thai literature and folktales have been passed down to the present day and included in contemporary children's literature: repetition, recreation, parody and transformation. This analytical study confirms the theory of intertextuality which believes that every text absorbs elements from other works and transforms the content of previous texts. They may refer directly to the original works or interpret them in order to present new meanings or satirize certain literary conventions and motifs, as can be seen in The Little Garuda, The Magicless Prince, The Adventure of Macchanu, The Adventure in Himavant Forest and The Fantastical Himavant, for example. The authors of these books may intend to conserve only some elements of the narration from the old days and recreate them for new generations of readers. Therefore, reality, possibility and modernity are important reasons for the adaptation. The transformation of traditional literature into picture books is an interesting strategy to introduce young readers to read folktales and traditional literary works. But some of them, such as Kraithong and Aphai Mani Saga, keep only the names of the main characters and some incidents, then, new stories are created around them. In this way, it may be said that contemporary children's literature may both conserve and destroy traditional literature. Moreover, some contemporary children's literary works which are written in prose may not be able to conserve traditional literary aesthetics. The examples mentioned in this article have differing degrees of quality and value. This cannot be denied and should be the subject of further study. Therefore, the accumulated legacy from traditional literature reveals that literature and literary conventions are always dynamic and subject to constant revival and renewal.

\section{References}

Bhuthayodphachulalok Prabatsomdejpra. 1997. Bot Lakhon Ru'ang Ramakian. Bangkok: The Fine Arts Department. [in Thai] 
Compagnon, Antoine. 2004. Literature, Theory, and Common Sense translated by Carol Cosman. Oxford: Princeton University Press.

Fen Studio. 2002. Ramavatal. Bangkok: Bunlue. [in Thai]

Fen Studio. 2002. Suk Mahabharata. Bangkok: Bunlue. [in Thai]

Kraithong. 2004. Bangkok: Buraphat Comic. [in Thai]

Koynuch. 2002. Khrut Noi (The Little Garada). Bangkok: Amarin. [in Thai]

Kitakal. 2004. Macchanu Phachonphai (The Adventure of Macchanu). Bangkok: Amarin. [in Thai]

Nopporn Prachakul. 2000. Intertextuality. Sarakadee 16.182:175-77. [in Thai]

P. na Pramualmark. 1972. Nithan Kham Klon Sunthon Phu. Vol.2.

Bangkok: Bhaebhitaya. [in Thai]

Preeda Ukrachandachot. 2003. Chaochai Mai Wises (The Magicless Prince) Bangkok: Amarin. [in Thai]

Sirikan. 2003. Talui dan Himavant (The Adventure in Himavant Forest). Bangkok: Fantasia. [in Thai]

Sirikan. 2003. Himavant Niramit (The Fantastical Himavant) Bangkok: Fantasia. [in Thai]

Thanakit. 1996. 50 Thai Tales. Bangkok: Suwiriyasarn. [in Thai]
Trisilpa Boonkhachorn. 2003. Wannakadee Priepthiep: Krabuantat lae Withikan (Comparative Literature: Paradigm and Method). Bangkok: Chulalongkorn University. [in Thai] 